American Journal of Animal and Veterinary Sciences 5 (3): 215-220, 2010

ISSN 1557-4555

(C) 2010 Science Publications

\title{
Diarrhea in Pre-Weaned Calves: Relative Risk Rates for Morbidity and Mortality in 13 Commercial Farms of Hot Arid Zone
}

\author{
M.A. Razzaque, T. Al-Mutawa and S.A. Mohammed \\ Department of Aridland Agriculture and Greenery, \\ Kuwait Institute for Scientific Research, P.O. Box 24885, Safat 13109, Kuwait
}

\begin{abstract}
Problem statement: In many hot arid countries, pregnant Holstein Friesian heifers are imported for herd replacement. The calves obtained from exotic cows are exposed to adverse climate in feedlot system resulting in very high morbidity and mortality rates. Diarrhea, dehydration and deaths are causing a major loss to the producers. This study examines the Risk Rates (RR) for morbidity and mortality in pre-weaned calves. Approach: Thirteen commercial dairy farms of small, medium and large sizes were surveyed using 1,280 newborn calves. A survey was conducted for calves from their birth to weaning at 90 day. Parameters of the study were birth weights, colostrum feeding, growth rate, incidences of diseases, clinical symptoms, post-mortem findings and results of laboratory investigations of samples obtained from sick and dead calves. Calf housing and feeding management of 13 farms were investigated. Results: RR for morbidity and mortality ranged from $0.3-1.00$ and being highest during the first week. Most common disease was diarrhea representing $90.6 \%$ of the total calves affected. Common pathogens causing diarrhea were E. coli, Salmonella sp. Klebsiella, Pasturella and rotavirus. Relationship between calf management and morbidity RR for diarrhea was significant $\left(\mathrm{r}^{2}=627, \mathrm{p}=0.01\right)$ and the growth rate was positively correlated $\left(r^{2}=0.761, p=0.1\right)$. Diarrhea caused a significant negative impact on gross margins of the calf enterprises. Conclusion: Colostrum feeding and housing management were the key factors for causing a high RR for morbidity and mortality. Gross margin loss was significantly influenced by morbidity and mortality RR of calves.
\end{abstract}

Key words: Calf, diarrhea, morbidity, mortality, gross-margin, E. coli, pre-weaned calves

\section{INTRODUCTION}

In countries of hot arid zone, high calf morbidity and mortality risks represent a major economic loss to the dairy operations (Svenssson et al., 2006). The most common cause of calf-hood disease was diarrhea (Wudu et al., 2008) during their early ages, followed by pneumonia, joint ills, septicemia word (Razzaque et al., 2009a; Gulliksen et al., 2008). In addition to economic losses, calf-hood diarrhea has public health significance due to zoonosis associated with food borne diseases and antibiotics residues derived from treated calves. Recent studies of Razzaque et al. (2009b) showed that losses of profits due to calf mortality in hot arid zone was very high ranging from $12-61 \%$ of the gross revenue. The most common causes of diarrheal diseases in pre-weaned calves (Razzaque et al., 2009a) were bacteria (E. coli, Salmonella sp. and Klebsiella) and virus (Coranovirus and rotavirus). Razzaque et al. (2009c) found that individual hutch housing of calves played an important role in combating calf-hood diseases. On-time identification of causes of diarrhea and improvement of passive immunity, hygienic feeding and management of calves were found to be the key elements for reducing calf losses in the commercial dairy farms (Razzaque et al., 2009c). Present study examines the relative morbidity and mortality Risk Rates (RR) of commercial dairy farms of Kuwait and gross margins of calf enterprise in dairy farms affected by diarrhea through on farm survey studies.

\section{MATERIALS AND METHODS}

Study site and climate: The dairy farms were located in the Government assigned site at sulaibiya $25 \mathrm{~km}$ away from the Kuwait city. The climate in the country has four seasons: Summer, autumn, winter and spring. Summer extends over June to September, this season is mostly dry and the temperature can exceed $48^{\circ} \mathrm{C}$ at daytime with a low Relative Humidity $(\mathrm{RH})$ ranging

Corresponding Author: M.A. Razzaque, Department of Aridland Agriculture and Greenery,

Kuwait Institute for Scientific Research, P.O. Box 24885, Safat 13109, Kuwait

Tel: +965 24989828 Fax: (965) 2498-9809 
from $10-50 \%$. RH increases after August to September and then temperature declines. During the Autumn season (October and November) temperature declines to 30 and $20^{\circ} \mathrm{C}$ respectively at daytime having a $\mathrm{RH}$ ranging 50-90\%. Winter season extends from December to March and temperature can reach a low as $-4^{\circ} \mathrm{C}$ in January at night and as high as $10-19^{\circ} \mathrm{C}$ at daytime. Spring season covers part of March to May with a temperature $20-30^{\circ} \mathrm{C}$ at daytime.

Survey study: Thirteen (13) commercial dairy farms were used out of a total 29 dairy farms of the country. These farms were of 3 main categories: 4 large $(>500$ adult cattle), 5 medium (250-499 cattle) and 4 small (<249 cattle). The dairy cattle population used in the study represented $56 \%$ of the total 11,760 adult herds. A survey format was designed to include important variables of calves from their birth to weaning at 90d. The records of a total of 1,280 newborn Holstein Friesian calves at their birth to the advancing ages were included. Those were mainly type of deliveries, colostrum feeding, diarrheal diseases, clinical symptoms of sick calves, calves died postmortem findings and laboratory investigation of the samples submitted from the sick calves and dead calves. Biological samples obtained from the sick and dead calves and fecal samples were used for identification of bacterial and viral infections according to Bruckner et al. (2007).

Criteria for scoring the calf management and feeding data were used for assessing the calf performance in the farms (Razzaque et al., 2009d). Data of all calves born during the calving season were analyzed (Ross and Payne, 2002) for statistical analysis of risk rates for morbidity and mortality as well as for calf management scores.
Risk Rate (RR): RR cumulative incidence was calculated using the formula:

Number of calves acquiring the event of interest/initial number of animals at risk-half (1/2) the withdrawal (excluding the animals acquiring the event).

Case fatality rate (the risk of death in an animal with a specific disease): Case fatality rate was calculated using the formula: Total deaths within a specified time after diagnosis/total number of animals acquiring the disease.

Gross margin analysis of diarrheal diseases: All of the total 13 commercial dairy farms were surveyed for the diarrheal diseases. However calf enterprise variable costs were determined for feeds, labor and veterinary input costs for only 6 farms, farm IDs 2, 4, 6, 9, 11 and 13 could be obtained as these farms had incomplete records Table 6 .

\section{RESULTS}

Risk Rate (RR) for morbidity and mortality: The RR for morbidity and mortality had ranged from 0.05-1.00 and 0.03-1.00 respectively Table 1 . The risk of morbidity and mortality in calves was highest during the first two weeks calf life, when $89.2 \%$ of the total cases of morbidity and $50.3 \%$ of the total deaths occurred. Farm 12 lost all of its 27 calves born during the calving season. Most common disease was diarrhea resulting in dehydration of calves representing $53 \%$ of the total 1,280 calves surveyed. Combined mean case fatality rate was $48.9 \%$ and mean RR for morbidity and mortality were 0.59 and 0.29 respectively Table 1 .

Causes of diarrhea: Enterogenic pathogens causing diarrhea and diarrhea combined with septicemia were Escherichia coli and Salmonella sp., Table 2.

Table 1: Diarrhea cases, disease-specific morbidity and mortality risk rates and case fatality rates on surveyed farms in 1998/99

\begin{tabular}{|c|c|c|c|c|c|c|}
\hline Farm ID No. & $\begin{array}{l}\text { Calves affected } \\
\text { by disease (No.)* }\end{array}$ & $\begin{array}{l}\text { Diarrhea } \\
\text { cases (No.)** }^{* *}\end{array}$ & $\begin{array}{l}\text { Diarrhea } \\
\text { deaths (No.) }\end{array}$ & $\begin{array}{l}\text { Case fatality } \\
\text { rate }(\%)\end{array}$ & $\begin{array}{l}\text { Risk rate for } \\
\text { morbidity ( } 0-1 \text { scale) }\end{array}$ & $\begin{array}{l}\text { Risk rate for } \\
\text { mortality ( } 0-1 \text { scale })\end{array}$ \\
\hline 1 & 293 & 275 & 91 & 33.09 & 0.96 & 0.32 \\
\hline 2 & 140 & 129 & 45 & 34.88 & 0.60 & 0.21 \\
\hline 4 & 10 & 10 & 5 & 50.00 & 0.40 & 0.20 \\
\hline 5 & 9 & 5 & 3 & 60.00 & 0.05 & 0.03 \\
\hline 6 & 7 & 6 & 4 & 66.67 & 0.05 & 0.03 \\
\hline 7 & 9 & 9 & 8 & 88.89 & 0.33 & 0.30 \\
\hline 8 & 13 & 6 & 4 & 66.67 & 0.10 & 0.06 \\
\hline 9 & 62 & 61 & 53 & 86.89 & 0.79 & 0.69 \\
\hline 10 & 31 & 27 & 8 & 29.63 & 0.77 & 0.23 \\
\hline 11 & 36 & 31 & 25 & 80.65 & 0.54 & 0.44 \\
\hline 12 & 27 & 27 & 27 & 1000 & 1.00 & 1.00 \\
\hline 13 & 112 & 92 & 57 & 61.96 & 0.74 & 0.46 \\
\hline Total & 749 & 678 & 330 & 48.67 & 0.59 & 0.29 \\
\hline
\end{tabular}

*: Not including 15 calves that had a repeat attack of diarrhea; **: Not including an additional 15 repeat cases 
Table 2: Bacteria and rotavirus isolations from individual farms

\begin{tabular}{|c|c|c|c|c|c|c|}
\hline \multirow[b]{3}{*}{ Farm ID } & \multirow{3}{*}{$\begin{array}{l}\text { Total } \\
\text { number } \\
\text { examined }\end{array}$} & \multicolumn{5}{|c|}{ Number of positive cases } \\
\hline & & \multirow[b]{2}{*}{ Rotavirus } & \multirow{2}{*}{$\begin{array}{l}\text { E. colil } \\
\text { Klebsiellal } \\
\text { Pastuerella }\end{array}$} & \multicolumn{3}{|c|}{ Salmonella } \\
\hline & & & & $\mathrm{B}(*)$ & $\mathrm{C}$ & $\mathrm{E}$ \\
\hline 1 & 5 & 2 & 2 & & 1 & 1 \\
\hline 2 & 17 & 1 & 4 & 1 & & 2 \\
\hline 4 & 16 & 2 & 6 & & & 1 \\
\hline 5 & 16 & 3 & 2 & & & 1 \\
\hline 6 & 23 & 2 & 10 & & 1 & \\
\hline 7 & 3 & & 2 & & & 1 \\
\hline 8 & 5 & 2 & 1 & & & 1 \\
\hline 9 & 28 & 3 & 14 & & 3 & 2 \\
\hline 10 & 3 & 1 & 1 & 1 & & \\
\hline 11 & 20 & & 9 & & 1 & 1 \\
\hline 12 & 6 & 1 & 4 & & & 2 \\
\hline 13 & 30 & 3 & 8 & 1 & 1 & 8 \\
\hline
\end{tabular}

Table 3: Effects of calf-herd size on mortality Risk Rates (RR) and daily liveweight of preweaned calves daily growth rate of calves on surveyed farms

\begin{tabular}{lllll}
\hline $\begin{array}{l}\text { Farm } \\
\text { ID }\end{array}$ & $\begin{array}{l}\text { Calf herd } \\
\text { size }\end{array}$ & $\begin{array}{l}\text { No. calves } \\
\text { sampled }\end{array}$ & $\begin{array}{l}\text { RR 0-1 } \\
\text { scale }\end{array}$ & $\begin{array}{l}\text { Mean }( \pm \text { SE) daily } \\
\text { Live-weight gain } \\
\left(\mathrm{g} \mathrm{day}^{-1}\right)\end{array}$ \\
\hline 1 & 386 & 6 & 0.34 & $644 \pm 51.9$ \\
2 & 215 & 50 & 0.24 & $409 \pm 18.0$ \\
4 & 25 & 12 & 0.20 & $418 \pm 37.2$ \\
5 & 106 & 38 & 0.07 & $552 \pm 32.9$ \\
6 & 133 & 21 & 0.04 & $414 \pm 15.9$ \\
7 & 29 & 3 & 0.30 & $476 \pm 30.7$ \\
8 & 65 & 14 & 0.15 & $522 \pm 33.1$ \\
9 & 77 & 4 & 0.70 & $465 \pm 55.0$ \\
10 & 35 & 0 & 0.31 & N/A \\
11 & 57 & 10 & 0.51 & $475 \pm 45.5$ \\
12 & 27 & 0 & 1.00 & N/A \\
13 & 125 & 29 & 0.58 & $404 \pm 23.9$ \\
& & & & $* 460 \pm 11.3$ \\
\hline
\end{tabular}

*: Overall mean

In diarrhea cases, $76.2 \%$ of $(16 / 21)$ of the $E$. coli isolates occurred in young calves of ages from birth to 10d, while Salmonella sp., occurred in a wider range of ages from birth to 26d. Rotavirus was the most commonly found pathogen in all farms on average $10 \%$ of the total sample examined. Klebsiella occurred along with E. coli in diarrheal calves. Pasteurella sp. occurred only $6.5 \%$ of total sample examined (table not presented). Salmonella sero types B, C and E were isolated and combinedly represented $15 \%$ of total samples. Unidentified cause of diarrhea accounted for $3.3 \%$ of the diarrhea affected calves.

Relative calf-herd size and growth rate: Daily growth rate varied widely within individual farm and between the farms with a range from 404 $\pm 11.3-644 \pm 51.9 \mathrm{~g} \mathrm{~h}^{-1}$ day $^{-1}$ with a mean \pm SD of $460 \pm 11.3 \mathrm{~g} \mathrm{~h}^{-1}$ day $^{-1}$ Table 3 . Calfherd sizes had no significant effect on mortality RR and daily live weight gain.

Calf housing and feeding management: The analysis showed a negative correlation between calf management and morbidity and mortality RR Table 5. The relationship between diarrhea morbidity and management score was significant $\left(\mathrm{r}^{2}=0.627\right.$, $\mathrm{p}=0.01)$. The feeding was also positively correlated with the growth rate $\left(r^{2}=0.761 ; p=0.01\right)$.

Gross margin analysis: The variable costs/calf ranged from KD 3.85 (US\$ 13.32)-KD 18.34 (US\$ 63.45) for labor and KD 21.52 (US\$ 74.46)-KD 30.44 (US\$ 105.32) for feeds depending on the management and number of calves in the farms Table 6 . The gross margin Table 6 ranged widely between the calf farms ranging KD 52.17 (US\$ 180.50)-KD 92.70 (US\$ 320.74). These differences in the gross margin were primarily due to differences in losses of pre-weaned calves Table 1 .

\section{DISCUSSION}

The calves from their birth to weaning at $90 \mathrm{~d}$ of hot arid region are mostly raised under feedlot management system. They are housed in metallic crates in the confined closed type environment, therefore, chances of pathogen spread are very high. A crude mortality rate $(43.6 \%)$ was reported in Kuwait (Razzaque et al., 2009a). Most of the deaths in young calves found in Kuwait were due to diarrhea Table 1. Out of 749 calves affected by the diseases, $90.6 \%$ were caused by diarrhea, therefore, it was considered as a killer disease. Besides arid zone, in many other countries like Pakistan and Ethiopia, severe problems of diarrheal diseases in young calves were observed (Wudu et al., 2008).

Causes of diarrhea in young calves: Most pathogens isolated were E. coli, Pastuerella, Salmonella sp. (types B, C and E), Klebsiella and Rotavirus Table 2. Farm to farm variations of pathogens were large depending on the calf housing and feeding and management practices Table 4. Among the Salmonella strains B, C and E represented $10,23.4$ and $66.7 \%$ of the total identified strains respectively. The dairy farms under our study were close to one another (5-50 m apart only) and the rodents, birds and humans were found to be the carriers of the Salmonella sp. 
American J. Animal \& Vet. Sci., 5 (3): 215-220, 2010

Table 4: Criteria and scores awarded for assessing calf housing and feeding management

\begin{tabular}{|c|c|c|c|c|c|c|c|c|c|c|c|c|}
\hline \multirow[b]{2}{*}{ Housing variables } & \multicolumn{12}{|c|}{ Farm ID } \\
\hline & 1 & 2 & 4 & 5 & 6 & 7 & 8 & 9 & 10 & 11 & 12 & 13 \\
\hline Separate facility precalving/calving & 0 & 0 & 0 & 1 & 1 & 0 & 0 & 0 & 0 & 0 & 0 & 0 \\
\hline Low stocking rate $<5 /$ Pen & 0 & 0 & 0 & 1 & 1 & 0 & 0 & 0 & 0 & 0 & 0 & 0 \\
\hline Regular cleaning of calving pen & 0 & 0 & 0 & 1 & 1 & 0 & 1 & 0 & 0 & 0 & 0 & 0 \\
\hline $\begin{array}{l}\text { Colostrum feeding removal of calf } \\
\text { after delivery }\end{array}$ & 1 & 1 & 1 & 1 & 1 & 0 & 1 & 0 & 0 & 1 & 1 & 1 \\
\hline Individual calf crate or $<10 /$ pen & 1 & 1 & 1 & 1 & 1 & 1 & 1 & 0 & 0 & 0 & 0 & 0 \\
\hline Cleaning system with disinfection & 0 & 0 & 0 & 1 & 1 & 0 & 1 & 0 & 0 & 0 & 0 & 0 \\
\hline Effective heating & 0 & 0 & 0 & 1 & 1 & 0 & 0 & 0 & 0 & 0 & 0 & 0 \\
\hline Isolation of sick calf and disinfection & 0 & 0 & 0 & 0 & 0 & 0 & 1 & 0 & 0 & 0 & 0 & 0 \\
\hline \multicolumn{12}{|l|}{ Feeding } & 1 \\
\hline Colostrum feeding supervised/forced & 1 & 1 & 1 & 1 & 1 & 0 & 1 & 0 & 0 & 1 & 0 & 0 \\
\hline Individual calf feeding method & 1 & 1 & 1 & 1 & 1 & 1 & 1 & 0 & 0 & 1 & 0 & 0 \\
\hline Whole milk/milk replacer quality & 1 & 1 & 1 & 1 & 1 & 1 & 1 & 1 & 0 & 1 & 1 & 1 \\
\hline Amount $5 \%$ BW×2 Daily or $51 / d$ & 1 & 0 & 0 & 1 & 0 & 0 & 0 & 0 & 0 & 0 & 0 & 0 \\
\hline Concentrate from few days of age & 1 & 1 & 1 & 1 & 1 & 1 & 1 & 1 & 1 & 1 & 1 & 1 \\
\hline Freshwater available & 1 & 0 & 0 & 1 & 1 & 1 & 1 & 1 & 1 & 1 & 1 & 1 \\
\hline Weaned from milk on $>2 \mathrm{~kg}$ conc. day ${ }^{-1}$ & 1 & 1 & 1 & 1 & 1 & 1 & 1 & 1 & 1 & 1 & 1 & 1 \\
\hline Hay fed from a few days of age & 1 & 0 & 0 & 0 & 0 & 0 & 0 & 1 & 1 & 0 & 0 & 0 \\
\hline Total score for feeding & 8 & 5 & 5 & 7 & 6 & 5 & 6 & 5 & 4 & 6 & 4 & 4 \\
\hline
\end{tabular}

Table 5: Linear correlation between calf management scores and morbidity, mortality and growth rates

\begin{tabular}{lll}
\hline Variable & Calf management $\left(\mathrm{r}^{2}\right)$ & Feeding management $\left(\mathrm{r}^{2}\right)$ \\
\hline Morbidity RR* & $0.633(\mathrm{p}<0.01)$ & - \\
$\begin{array}{l}\text { Mortality RR } \\
\text { Morbidity RR }\end{array}$ & $0.460(\mathrm{p}<0.05)$ & - \\
$\begin{array}{l}\text { Diarrhoea }) \\
\text { Mortality RR }\end{array}$ & $0.627(\mathrm{p}<0.01)$ & - \\
(Diarrhoea) & $0.428(\mathrm{p}<0.05)$ & - \\
Growth rate/d & - & $0.761(\mathrm{p}<0.01)$ \\
\hline *: RR = Risk Rate &
\end{tabular}

The bacteria identified in Kuwait Table 2 were mainly enteric, enterotoxigenic K-99 strain E. coli and septicemic Salmonella. Over 50\% of the calves had low level of immunoglobulins and serum proteins than acceptable levels and standard recommended by Orro et al. (2008). Colostrum composition and its management were found to play a major role in preventing calf diarrhea (Kehoe et al., 2007). Post-mortem examinations revealed gross pathological changes of Peyr's patches and ileum as observed by Zhang et al. (2002). The Salmonella serotype B was found to be the main cause of diarrhea and mostly spread by the rodents, bird, humans and vehicles. These findings were consistent with the observations of Costello (2010) who found that above means of transmission of Salmonella were very common in dairy operations in other countries.

Diarrhea associated with mild to severe dehydration was very common in our calves, therefore, electrolyte therapy was used for the dehydrated calves. The calves with mild diarrhea and septicemia survived, yet the mortality RR was found to be very high Table 1.
Gulliksen et al. (2008) noted that calf diarrhea was a major ailment caused by several pathogens and the predisposing factors were mainly the lack of colostrum, failure to absorb cloistral antibody (Razzaque et al., 2009d) adverse nutritional and adverse environmental effects. All these factors were found to be common in hot arid zone including Kuwait (Razzaque et al., 2009a) and in the farms of similar management practices (Trotz-Williams et al., 2008). The results of our study suggest that housing and feeding management of calves of Kuwait's dairy herds played major role in predisposing young calves to a high morbidity and mortality RR Table 1 and 4.

Diarrhea can be caused by both non-infectious and infectious agents (Costello, 2010). Noninfectious causes of diarrhea in young calves are dietary changes, overfeeding and changing of milk replacer brands. In our study non-infectious diarrhea was rare, as the milk replacers used were from the same source and of the same brand. The calf starters were farm made, using common feed ingredients and overfeeding was avoided.

Growth rate of pre-weaned calves: Due to the adverse effects of diarrheal diseases and presumably environment factors as well such as housing/feeding management had significantly $(\mathrm{p}=0.05)$ affected the growth rates of calves Table 3. A mean daily gain of calves was $460 \pm 23.9 \mathrm{~g} \mathrm{~h}^{-1}$ which was well below the expected daily gain ranging from $600 \mathrm{~g}-950 \mathrm{~g} \mathrm{~h}^{-1}$ depending on the type and quality of milk replacers and calf starter fed (Yarlagadda and Lee, 2008; Bach et al., 2007). 
American J. Animal \& Vet. Sci., 5 (3): 215-220, 2010

Table 6: Calf enterprise income and expenditure (KD**): gross margin analysis of six farms

\begin{tabular}{|c|c|c|c|c|c|c|}
\hline \multirow[b]{2}{*}{ Economic variable } & \multicolumn{6}{|l|}{ Farm ID } \\
\hline & 2 & 4 & 6 & 9 & 11 & 13 \\
\hline \multicolumn{7}{|l|}{ Income (KD)** mortality } \\
\hline Number of calves born & 278.00 & 133.00 & 380.00 & 218.00 & 108.00 & 179.00 \\
\hline Number of calves reared & 181.00 & 66.00 & 249.00 & 55.00 & 41.00 & 85.00 \\
\hline No. of calf deaths $<1 \mathrm{wk}$ & 78.00 & 22.00 & 31.00 & 147.00 & 48.00 & 32.00 \\
\hline No. of calf deaths 2 wk- 3 mo & 19.00 & 12.00 & 10.00 & 16.00 & 19.00 & 62.00 \\
\hline Total death & 97.00 & 34.00 & 41.00 & 163.00 & 67.00 & 92.00 \\
\hline Calf value@1 wk & 50.00 & 50.00 & 50.00 & 50.00 & 50.00 & 50.00 \\
\hline Calf value@3 mo & 100.00 & 100.00 & 100.00 & 100.00 & 100.00 & 100.00 \\
\hline Income calf sales & $18,100.00$ & $8,250.00$ & $29,400.00$ & $5,500.00$ & $4,100.00$ & $8,500.00$ \\
\hline \multicolumn{7}{|l|}{ Calf enterprise variable costs } \\
\hline Labor: Total & 960.00 & 840.00 & 958.00 & 719.00 & 712.80 & 1559.00 \\
\hline (Cost/calf) & $(5.30)$ & (12.73) & (3.85) & (13.07) & (17.39) & (18.34) \\
\hline Feed: Total & $4,064.40$ & $1,940.90$ & $5,358.30$ & $1,626.50$ & $1,248.00$ & $2,157.9$ \\
\hline Cost/calf & $(22.45)$ & $(29.41)$ & $(21.52)$ & $(29.44)$ & (30.44) & (25.39) \\
\hline Animal health, Power*, Water* & 60.45 & 61.31 & 445.71 & 103.950 & 54.69 & 155.55 \\
\hline Cost/calf & 0.33 & 0.93 & 1.79 & 1.89 & 1.33 & 3.79 \\
\hline Administration, Rep, maintenance of buildings & 212.31 & 94.84 & 362.65 & 191.02 & 89.05 & 153.32 \\
\hline Total cost & $5,297.16$ & $2,937.05$ & $7,124.66$ & $2,640.47$ & $2,104.54$ & $4,025.77$ \\
\hline Gross margin: Total & $12,802.84$ & $5,312.95$ & $22,275.34$ & $2,859.53$ & $1,995.46$ & $4,474.23$ \\
\hline Gross margin/calf reared & $70.72^{\mathrm{b}}$ & $80.50^{\mathrm{a}}$ & $89.46^{\mathrm{a}}$ & $51.99^{\mathrm{c}}$ & $48.67^{\mathrm{c}}$ & $52.64^{\mathrm{c}}$ \\
\hline
\end{tabular}

Gross profit/margin: Diarrhea caused a significant adverse economic impact on gross margin of all 13 dairy farms Table 6.These adverse effects were directly related to the magnitude of calf mortality rate. Due to very high costs of labor and animal health for taking care of sick calves in farm nos. 9, 11 and 13 had significantly lower gross margin/calf reared Table 6 . Feed cost ranged from KD 21.52 (US \$ 74.46)-KD 30.44 (US \$ 105.33) per calf from birth to weaning Table 6. These costs are much higher than those reported for other countries due to high costs of imported milk replacers and feed ingredient cost for calf starters in Kuwait (Razzaque et al., 2009b).

\section{CONCLUSION}

Major cause of high Risk Rates (RR) for morbidity and mortality in pre-weaned calves was diarrhea. Ontime colostrum feeding and housing management interventions were the key factors in reducing calf losses in feedlot farms of hot arid zone. Gross margin loss was significantly influenced by morbidity and mortality RR of calves.

\section{ACKNOWLEDGEMENT}

Dairy farms and cattle herds were provided by the Kuwait's dairy producers. The expert advice of Dr. David Scharp and Dr. Peter Moorehouse of GRM, epidemiology and statistical analyses, Australia are appreciated. Kuwait Foundation for the Advancement of Sciences (KFAS) provided partial support for the studies. Animal Health Department of Public Authority for Agricultural Affairs and Fish Resources (PAAFR) carried out the diagnosis of pathogens. Technical assistance of Ms. Mini Jacob, Ms. Shalini Mathew, Ms. Sheeba Albert and secretarial study of Ms. Shiji Thomas for the preparation of the study are acknowledged.

\section{REFERENCES}

Bach, A., A. Gimenez, J.L. Juaristi and J. Ahedo, 2007. Effects of physical form of a starter for dairy replacement calves on feed intake and performance. J. Dairy. Sci., 90: 3028-3033. DOI: 10.3168/jds.2006-761

Bruckner, G., C. Bruschke, S. Edwards and B. Vallat, 2007. The OIE network of reference laboratories. J. Wildlife Dis., 43: 60-63. http://www.jwildlifedis.org/cgi/content/full/43/3_S upplement/S60

Costello, R., 2010. Calf scours: Causative agents of calfhood diarrhea. http://www.merricks.com/tech_calfscours.html

Gulliksen, S.M., K.I. Lie, T. Loken and O. Osteras, 2008. Calf mortality in Norwegian dairy herds. J. Dairy. Sci., 92: 2782-2795.

Kehoe, S.I., B.M. Jayarao and A.J. Heinrichs, 2007. A survey of bovine colostrum composition and colostrum management practices on pennsylvania dairy farms. Am. J. Dairy Sci., 90: 4108-4116. DOI: $10.3168 /$ jds.2007-0040 
Orro, T., S. Jacobsen, J.P. LePage, T. Niewold and S. Alasuulari et al., 2008. Temporal changes in serum concentrations of acute phase proteins in newborn dairy calves. Vet. J., 176: 182-187. DOI: 10.1016/J.TVJL.2007.02.010

Razzaque, M.A., S. Abbas, T. Al-Mutawa and M. Bedair, 2009a. Mortality of pre-weaned calves in Kuwait's dairy herds, its causes and impact of interventions. Int. J. Vet. Med. 5: 1-12.

Razzaque, M.A., M. Bedair, S. Abbas and T. AlMutawa, 2009b. Economic impact of calf mortality on dairy farms in Kuwait. Pak. Vet. J., 29: 97-101. http://pvj.com.pk/pdf-files/29_3/97-101.pdf

Razzaque, M.A., S. Abbas, T. Al-Mutawa and M. Bedair, 2009c. Performance of pre-weaned female calves confined in housing and open environment hutches in Kuwait. Pak. Vet. J., 29: 1-4. http://pvj.com.pk/pdf-files/29_1/1-4.pdf

Razzaque, M.A., T. Al-Mutawa, S. Abbas and M. Bedair, 2009d. Performance of pre-weaned dairy calves under hot arid environment: Effects of immunoglobulins and age on diseases and mortality. Am. J. Applied Sci., 6: 1885-1891. http://www.scipub.org/fulltext/ajas/ajas61118851891.pdf

Ross, G. and R. Payne, 2002. Statistics in Agriculture. 1st Edn., A Hodder and Arnold Publication, Oxford, ISBN: 10: 0340760475, pp: 288.
Svenssson, C., A. Linder and S.O. Olsson, 2006. Mortality in Swedish dairy calves and replacement heifers. J. Dairy. Sci., 89: 4769-4777. PMID: 17106108

Trotz-Williams, L.A., K.E. Leslie and A.S. Peregrine, 2008. Passive immunity in ontario dairy calves and investigation of its association with calf management practices. J. Dairy. Sci., 91: 3840-3849. DOI: 10.3168/jds.2007-0898

Wudu, T., B. Kelay, H.M. Mekonnen, K. Tesfu, 2008. Calf morbidity and mortality in smallholder dairy farms in Ada'a Liben district of Oromia, Ethiopia. Trop. Anim. Health Prod., 40: 369-376. DOI: 10.1007/s11250-007-9104-3

Yarlagadda, S. and C.N. Lee, 2008. Utilizing wheat mill run for dairy calf and heifer feed. Cooperative Extension Service. http://www.ctahr.hawaii.edu/hnfas/publications/liv estock/wheatMillFeed.pdf

Zhang, S., L.S. Renato, M.T. Renee, S. Silke and H. Wolf-Dietrich et al., 2002. The Salmonella enteric serotype typhimurium effector proteins SipA, SopA, SopB, SopD and SopE2 act in concert to induce diarrhea in calves. Infect. Immunity, 70: 3843-3855. DOI: 10.1128/IAI.70.7.38433855.2002 